\title{
A Methodology for Increasing Business Process Maturity in Public Sector
}

\author{
Mojca Indihar Stemberger, Andrej Kovacic, and Jurij Jaklic \\ University of Ljubljana, Faculty of Economics \\ Ljubljana, Slovenia
}

\author{
mojca.stemberger@ef.uni-lj.si andrej.kovacic@ef.uni-lj.si \\ jurij.jaklic@ef.uni-lj.si
}

\begin{abstract}
Non-profit organizations such as public sector organizations have some specifics, which make renovation projects significantly different. It is clear that radical changes in the execution of business processes and in the organizational structures are not suitable for the public sector because they are not possible for many, also political, reasons. A business process change in public sector mostly means unification of business processes, automation of some activities and elimination of some unnecessary ones. Organizational changes are achievable only to a certain limit. Therefore classic business process renovation methodologies have to be adapted. The proposed methodology that is presented in the paper has been successfully applied in a process change project at one of the Slovene Ministries, which is presented as a case study. Activities, techniques, and tools are proposed for each of the six traditional business process change project's stages. Problems and topics to which special attention has to be paid are also discussed.
\end{abstract}

Keywords: business process management, methodology, business process maturity, public sector, business process modeling, business process change, case study

\section{Introduction}

The need for business process improvement in public sector has been recognized many times. In 1990, during the period of many business process reengineering (BPR) projects, e.g. US government organizations went through the reform initiative named National Performance Review (Thompson, 2000), the main intention of which was organizational change. Several process change methods, that combine radical methods of BPR with a more progressive method of continuous process improvement, emerged (Hammer, 2004). Lately, they are particularly important when organizations are introducing ERP systems (Al-Mashari \& Zairi, 1999; Davenport, 1998), e-business (Bosilj-Vuksic, Indihar Stemberger, Jaklic, \& Kovacic, 2002), or SCM systems

(Trkman, Indihar Stemberger, \& Jaklic, 2002).

Material published as part of this publication, either on-line or in print, is copyrighted by the Informing Science Institute. Permission to make digital or paper copy of part or all of these works for personal or classroom use is granted without fee provided that the copies are not made or distributed for profit or commercial advantage AND that copies 1) bear this notice in full and 2) give the full citation on the first page. It is permissible to abstract these works so long as credit is given. To copy in all other cases or to republish or to post on a server or to redistribute to lists requires specific permission and payment of a fee. Contact Publisher@InformingScience.org to request redistribution permission.

It is clear that radical changes in the execution of business processes and in the organizational structures are not suitable for the public sector because they are not possible for many, also political, reasons. Business process change in the public sector mostly means unification of business processes, automation of some activities and elimination of 
some unnecessary ones. Organizational changes are achievable only to a certain limit. Therefore classic methodologies for process change projects have to be adapted to projects in the public sector. The purpose of the paper is to present the methodology for business process change that has been proven successfully in some governmental organizations, since it considers their specifics. Its effectiveness is analyzed using business process maturity levels. The methodology has been developed and successfully applied by the authors and other members of the Business Informatics Institute (BII).

The paper is structured as follows: the following section presents some theoretical foundations of business process change methodologies, while section three begins by describing the specifics of business process change projects in the public sector and proposes a methodology suitable for the public sector. The proposed methodology has been successfully applied in a process change project at one of the Slovene ministries, which is also presented as a case study illustrating the application of the methodology. Final remarks and some further research directions are given in the last section.

\section{Business Process Change}

Business process change (BPC) is a strategy-driven organizational initiative to improve and (re)design business processes to achieve competitive advantage in performance through changes in the relationships among management, information, technology, organizational structure, and people (McCormack \& Johnson, 2001). It integrates radical change methods of business process reengineering (Hammer \& Champy, 1993) and a more progressive methods of continuous process improvement with adequate information technology (IT) and e-business infra-structure strategies. The main difference of both groups of methods is between improvement, which essentially relies on a problem-solving approach, and reengineering, which relies on reconceptualizing how a business process should work. Most process change projects fall between these extremes (Harmon, 2003).

\section{Business Process Maturity}

To analyze an organization's understanding of its processes i.e. to measure its current position in becoming business process oriented, to compare (benchmark) to other organizations, to analyze changes to the process understanding, and consequently a BPC project's success, the Business Process Orientation (BPO) maturity model developed by McCormack and Johnson (2001) can be very useful. The BPO maturity model was designed as a reference model of the evolutionary stages that organizations go through to become business process oriented.

A BPO maturity model identifies five levels or steps that describe how an organization typically evolves from the functionally strong organization with barely visible processes stage to the integrated processes inside the organization and with its vendors and suppliers. The initial four-stage model described in McCormack and Johnson (2001) is extended in Lockamy and McCormack (2004) with the fifth stage related to the supply chain management. The following maturity stages are defined:

- Level 1 - Initial: Processes are unstructured and ill defined. Processes, activities and organizational structures are not based on horizontal processes, process performance is unpredictable. Processes costs are high, customers satisfaction is low, functional cooperation is also low.

- Level 2 - Defined: Basic processes are defined and documented, but activities and organization basically remain traditional. Processes costs remain high, customer satisfaction has improved, but is still low. 
- Level 3 - Linked: This level represents a breakthrough. Cooperation between company departments, vendors and customers is established. Broad process jobs and structures are put in place. Customer satisfaction begins to show considerable improvement.

- Level 4 - Integrated: The organization, its vendors and suppliers take cooperation to the process level. Organizational structures are based on processes, process performance measures and management systems are applied. As a consequence, processes and supply chain management costs are dramatically reduced.

- Level 5 - Extended: Competition is based on supply chains. Collaboration between companies is on the highest level, multi-firm supply chain management teams with common processes, goals, and broad authority take shape.

In McCormack and Johnson's (2001) research the relationship between business process maturity and performance is examined. They proved that BPO can contribute to the overall performance of an organization, however processes documentation alone is not enough; it is a foundation for organizing jobs and establishment of measures. Process measurement and process jobs have been shown to have strong relation-ships to business performance.

However, improvement and integration of business processes is not smooth. On the contrary, it is difficult because integrated business processes usually initially develop as "chained pairs" of activities and are later broadened to multi-stage or fully integrated chains. The activities, processes, risks, and costs are often differentially de-fined by each activity. Therefore usage of formal and fitting methodology is necessary for BPC projects.

\section{Methodologies of Business Process Change}

A methodology can be defined as a collection of problem-solving methods governed by a set of principles and a common philosophy for solving target problems (Kettinger, Teng, \& Guha, 1997). Many methodologies for BPC are known; some are described in Harmon (2003), Kettinger et al. (1997) and Tenner and DeToro (1997).

In Kettinger et al. (1997), a composite Stage-Activity (S-A) framework for BPC methodologies, techniques and tools was derived. The framework is based on the description of 25 BPC methodologies practiced by the leading process change consulting firms. The methodologies in BPC projects are tailored to clients' unique needs. A framework consists of six stages that are subdivided into major activities. The six stages can be categorized as to containing the following activities:

1. Envision - This stage typically involves the establishment of management commitment and vision, a review of business strategy and IT opportunities, and identification and selection of key business processes.

2. Initiate - This stage encompasses setting of project goals, project planning and organizing a project team.

3. Diagnose - In this stage the existing processes are documented and analyzed. The processes are decomposed to sub-processes and modeled with different techniques. The models of the existing processes (AS-IS models) are developed with process modeling tools. Many of these tools also allow for some type of quantitative analysis in the sense of activity-based costing or simulation analysis depending on the sophistication of the underlying modeling technique. The processes are analyzed by qualitative methods as well, because many inefficiencies and drawbacks can be observed from the model alone.

4. Redesign - In this stage a new process design is developed. This is accomplished by evaluating different alternative processes (TO-BE models) through brainstorming and 
creativity techniques and also by conducting simulation and other types of quantitative analysis that is also supported by modeling tools. The new design should meet strategic objectives. This stage also encompasses proposing changes in organizational structures and culture, management, human resources and information technology. IT employment for the automation of redesigned processes is planned.

5. Reconstruct - This stage has to ensure migration to new processes and requires much change management. During this stage IT platforms and systems are implemented and users go through training.

6. Evaluate - The last stage of the BPC methodology includes evaluation of process performance to determine whether the project met its goals. Often it involves link-age to a firm's TQM programs and business process management.

In Kettinger et al. (1997) it had been shown that any of the existing BPC methodologies can be matched with the framework and the same holds for the BII (Business Informatics Institute) methodology for public sector that is described in the next chapter. The authors also suggest customization of the framework based on unique project characteristics, like the project radicalness. The customization according to specifics of the public sector is also discussed in the next section.

\section{BII Methodology for the Public Sector}

In the past most of the business process change projects have been undertaken in profit-oriented organizations, therefore most methodologies for business process change projects have been proved for this type of organizations. Although a decade old, we found the observation by CatsBaril, W. and Thompson, R. (1995) still actual, namely that the concept of redesigning processes goes against the common culture in many public sector organizations, but on the other side taxpayers are increasingly comparing public sector to private sector, demanding better customer service. But do non-profit organizations such as public sector organizations have some specifics, which make renovation projects significantly different?

Although the differences between business and government are blurring (Hendrick, 1994), several differences that are crucial to be considered in BPC projects are ascertained in literature. Governmental organizations have a unique culture and face many challenges due to their social obligations and higher legislative and public accountability (Kumar, Maheshwari, \& Kumar, 2002). Hendrick (1994) asserts that the objectives of government are less clear, clients and stakeholders are more diverse and numerous, and concepts such as quality are more complex.

In the literature review of e-government challenges and success strategies report (Gil-Garcia \& Pardo, 2005), among organizational and managerial challenges, concerning the lack of alignment between organizational goals and the IT project, the existence of multiple, sometimes conflicting, goals, and concerning the individual interests and associated behaviors that cause resistance to change and internal conflicts. Government agencies and programs also often act as independent and autonomous units without taking into account what other public organizations are doing.

Cats-Baril, W. and Thompson, R. (1995) observed the following specifics of the government among others: more constrains imposed by red tape, greater level of interdependence across organizational boundaries, higher level of extra-organizational linkages, greater interdependence across organizational boundaries, the turnover of top level administrators, the need to convince employees to change the existing organizational processes is greater, the difficulty to implement change is increased, and management tends to have less authority than its private sector counterparts.

This is in accordance with the Thompson's research (Thompson, 2000) on the National Performance Review (NPR) success, the main objectives of which were: downsizing, reducing adminis- 
trative costs, reforming administrative systems, decentralization of authority within agencies, empowerment of front-line workers, cultural change, quality of services improvement, and efficiency of agency work practices improvement. The research shows that some of the demands of the NPR, such as the decentralization of authority and cultural change, are difficult to enforce. According to Thompson the Social Security Administration agency is too big and dynamic for radical changes. Although the business process reengineering plan envisioned dramatic improvements in service and efficiency, the project ended up with less radical, incremental changes.

There are four major characteristics that should be considered in business process change (BPC) planning (Kettinger et al., 1997): (1) project radicalness, (2) process structuredness, (3) customer focus, and (4) the potential for IT enablement. By analyzing a typical BPC project in the public sector according to the above mentioned criteria, the following characteristics can be observed:

1. Although it would be possible to radically change some (or most) of the processes in the public sector, readiness for such radical changes is currently low in many public sector institutions. The organizational structures are often rigid, project resources are scarce, the ingenuous senior management commitment is usually difficult to achieve, several processes are predominantly intra-functional, culture supports status quo etc. All these characteristics support the belief that radical changes impose high risks.

2. Processes are mostly well structured; some of them are even governed by laws (e.g. administrative processes). However, many of them are partially semi-structured or not structured and they vary greatly in comparison with business, for example some professional activities, judgments.

3. Customer focus is more emphasized in the public sector as it had been in the past. Customer friendliness and simplification of procedures is the imperative of the government and administration. Very often this is the main motive for business process change in the public sector. However, in most cases the goal is not to attract new customers and keep the current ones. Customers are very often obligated to use these services, e.g. when someone wants to found a sports society it has to be registered by the state.

$\mathrm{BPC}$ projects in the public sectors have some common characteristics with projects in the private sector; however, it is necessary to customize the S-A framework for the public sector BPC projects due to the above observations and specifics. Since the radicalness of the projects in public sector is low, the emphasis should be on documenting the existing and analyzing processes as proposed by Kettinger et al. (1997).

The proposed methodology with the techniques and tools used is presented in the remaining part of this section. Also, the case of a BPC project at the Slovene Ministry of Education, Science, and Sport (Ministry), where the methodology has been used, is presented and the experience discussed.

Table 1 shows activities, techniques, and tools of the proposed methodology categorized by stages of a typical BPC project as proposed and validated by Kettinger et al. (1997) and discussed in the previous section.

\section{Envision}

Sincere commitment of the top management is considered to be the most important achievement of this stage and the critical success factor of the project. As ascertained by Thompson (2000) the sustained, demonstrated commitment of its top leadership to initiate and insist on the use of results-oriented management practices is necessary. In the public sector this could be one of the major problems due to the fact that this commitment is more of a formal nature, a consequence of 
public opinion pressure and not the truthful awareness of a need for a change. As business process changes in the public sector are very often strongly constrained and related to the changes of laws, by-laws, regulations, commitment of top management should include a will to make the necessary changes in the regulations which fall under their competence and sometimes also to propose changes of laws and by-laws.

Table 1. Methodology: Stages, activities, techniques, and tools of BII methodology for the public sector

\begin{tabular}{|c|c|c|c|}
\hline Stage & Activities & Techniques & Tools \\
\hline Envision & $\begin{array}{l}\text { Defining goals, purpose, and scope of } \\
\text { the project } \\
\text { Establishing management commitment }\end{array}$ & & \\
\hline Initiate & $\begin{array}{l}\text { Project planning } \\
\text { Organizing the project team } \\
\text { Organizing middle management work- } \\
\text { shops } \\
\text { Informing employees } \\
\text { Identifying key business processes } \\
\text { Identifying limitations and constraints }\end{array}$ & $\begin{array}{l}\text { Gantt chart } \\
\text { Brainstorming } \\
\text { Critical success factors } \\
\text { method }\end{array}$ & $\begin{array}{l}\text { Project management } \\
\text { tools }\end{array}$ \\
\hline Diagnose & $\begin{array}{l}\text { Organizing workgroups } \\
\text { Documenting processes } \\
\text { Business processes modeling } \\
\text { Confirming models } \\
\text { Verifying models } \\
\text { Analyzing the modeled business proc- } \\
\text { esses, organizational structures and } \\
\text { information system }\end{array}$ & $\begin{array}{l}\text { Structured interviews } \\
\text { BPMN or similar process } \\
\text { modeling technique } \\
\text { Process documentation form } \\
\text { Activity documentation form } \\
\text { Discrete event simulation }\end{array}$ & $\begin{array}{l}\text { Business process mod- } \\
\text { eling and simulation } \\
\text { tools }\end{array}$ \\
\hline Redesign & $\begin{array}{l}\text { Identifying groups of processes of the } \\
\text { same type } \\
\text { Proposing processes improvement and } \\
\text { unification } \\
\text { Proposing organizational changes } \\
\text { Modeling renewed processes } \\
\text { AS-IS and TO-BE processes mapping } \\
\text { Proposing IT projects } \\
\text { Verifying and changing proposals } \\
\text { Determining processes owners }\end{array}$ & $\begin{array}{l}\text { BPMN or similar process } \\
\text { modeling technique } \\
\text { Process change proposals } \\
\text { form } \\
\text { Current and renewed proc- } \\
\text { esses mapping tables } \\
\text { Organizational chart }\end{array}$ & $\begin{array}{l}\text { Business process mod- } \\
\text { eling and simulation } \\
\text { tools }\end{array}$ \\
\hline Reconstruct & $\begin{array}{l}\text { Implementing change } \\
\text { Planning and implementing IT projects }\end{array}$ & IS modeling techniques & $\begin{array}{l}\text { Project management } \\
\text { tools } \\
\text { CASE tools } \\
\end{array}$ \\
\hline Evaluate & $\begin{array}{l}\text { Implementing process monitoring sys- } \\
\text { tem and process management }\end{array}$ & & $\begin{array}{l}\text { Business process man- } \\
\text { agement tools }\end{array}$ \\
\hline
\end{tabular}

In the case of the Ministry the goal of the project was to do away with inefficiencies in business processes, to change the organizational structure, and to introduce suitable IT employment that will support redesigned business processes. The main purpose was to make the processes as customer friendly (not cumbersome, short etc.) as possible. This has also been the main objective in redesigning the processes. As the key to delivering quality services is decreasing variability (Hendrick, 1994), unification and standardization of processes were strongly emphasized. The awareness of the necessity to change the processes has been achieved, also because of the lucky coincidence: at the time when the project started, the Slovene government also started the socalled anti-bureaucratic program. 


\section{Initiate}

In this stage the project is initiated, which includes project planning (time, finance, outcomes), organization of the project team, and identification of the key business processes, which will be analyzed and redesigned.

In some organizations key business processes are already identified and listed but in others they are identified in a series of meetings using discussion and brainstorming techniques. Usually there are 5 to 10 key business processes (Harmon, 2003) that can be decomposed into several subprocesses.

Top management commitment for process changes at this stage should be transformed in a way that the employees of all levels understand the goals of the project. Resistance to changes should be diminished and full participation of employees in the project ensured. As the public sector organizations are usually more rigid than profit organizations, we propose that related activities should be even more emphasized in a public sector BPC project. We propose that several workshops for middle management should be organized and all employees be informed about the project, its goals, and the expected outcomes.

As noted earlier, one of the obstacles for a radical business process is the limitations of the current regulations, constraints of the common organizational rules and procedures at the governmental level etc. The project team has to be familiar with these limitations and constraints and moreover with the realistic possibilities to change these regulations, rules, procedures.

In the case of the Ministry the project group consisted of members from the Ministry and consultants from the Business Informatics Institute (BII). A workshop for the ministry project group was conducted, in which the participants were acquainted with project goals and the methodology used. The workshop identified the key processes, which fall into the following five groups, as well: (1) Strategic planning, (2) Working program preparation, (3) Preparation of laws and provisions, (4) Financial processes, and (5) Administrative processes.

The identification of the key processes was a three-phase process. Firstly, it was necessary for the project team members from the Ministry to fully understand the business process concept. Secondly, the list of all processes was prepared, and the last step was the selection of the processes to be renovated. The brainstorming technique was used in the second and the third step. Several criteria have to be used for the selection of processes. For example a process for which the renovation benefits are promising but has a very low frequency (e.g. once a year) was not considered for a change. A very useful technique at this point is identification of critical success factors (CSF) of the project. The identified critical success factors were:

- A well-defined goal of the project;

- Realistic expectations and proposals of changes;

- Management commitment should not be of a formal nature, just a consequence of public opinion pressure;

- Willingness to change or to initiate changes of the current laws, by-laws, and other regulations;

- Dissemination of project goals and understanding the necessity for a change;

- Changed state of mind to the "process way of thinking";

- Right identification and selection of the key processes;

- Selection of the appropriate tools. 
It can be derived from the above listed CSF that most of them are directly related to human factor implying a necessity for an efficient change management in all project phases.

\section{Diagnose}

The activities at this stage can be divided into two groups or phases. Firstly, the processes are modeled, and secondly they are analyzed. As radicalness of BPC projects in the public sector is usually low and the current processes will be improved, documentation and analysis of the existing processes are important and should be detailed.

\section{Business process modeling}

Models of business processes play an important role in different phases of business process (re)design regardless of the methodology used (Desel \& Ervin, 2000). The choice of a modeling technique and a tool for a particular project should be based on matching the virtues and limitations of various techniques with the objectives of the project.

Process simulation can be carried out for a detailed analysis of the AS-IS processes. Simulation has been applied many times in government for different purposes. As simulation requires plenty of resources and is a demanding task to be carried out, it should be carefully considered, which processes are candidates for such in-depth quantitative analysis. For example, it is not worth carrying out simulation for the processes of which the activity duration cannot be estimated precisely enough, or for the processes implemented only once a year. See (Popovic \& Jaklic, 2004) for a more detailed discussion on this topic.

Before the documentation activity of processes is conducted, workgroups are organized for different organizational units or areas. These workgroups consist of process actors, process modelers, and middle management. Since the understanding of the process concept is usually low at this stage, all actors are not yet known, so the workgroups can be expanded later. It is our experience that, despite workshops in earlier stages, actors and middle management usually fully understand the concept of processes, which flow through different organizational units, only when the process models are developed and presented.

Workgroups document the processes by means of structured interviews with activity actors. For documentation purposes two different forms are developed: the process documentation form and the activity documentation form. In this way all (sub)processes and activities are documented in the same manner. The process documentation form consists of the following elements: (sub)process name, (sub)process number, process' trigger(s) - events, inputs, detailed description, outputs, additional comments, proposals for improvements, evaluation (cycle time, frequency, splits and decision points frequencies for each output etc.). And the activity documentation form consists of: organizational unit, process name, activity number, activity name, actors and other required resources, inputs, detailed description, outputs, evaluation (average $/ \mathrm{min} / \mathrm{max}$ time, number of available resources, costs), additional comments and proposals for improvements, attachments. The documentation also includes organizational structure documentation and IS support documentation (description and additional comments).

Processes are usually modeled in several iterations. Designed models are presented to workgroup members, who change them according to their observations. The models have to be verified by consultants. It is essential for each process model and process description to be confirmed at the end of the modeling phase by a responsible person (usually a middle manager) to avoid possible misunderstandings in the future stages of the project.

For business process modeling we suggest using a technique that supports development of models, which are very clear and easily understood by non-specialists. Business Process Modeling 
Notation (BPMN) is becoming the de-facto standard technique for business process modeling and is supposed to be easy to use and understand, but also to provide the ability to model complex business processes.

In the case of the Ministry the processes were modeled by interviewing the actors and middle management. iGrafx Process tool, which supports the Enhanced Process Maps (EPM) modeling technique, was used for business process modeling. The EPM technique was selected, as at the time of the project planning the BPMN technique was not as well recognized as currently. Yet, it has all the required properties, such as simplicity and expressiveness, sufficient for the BPC type of projects and is very similar to BPMN.

This phase of the project was utterly resource consuming and lasted for almost six months. Models had to be changed several times based on the comments of the workgroup members and verification made by the consulting team. A number of ambiguities were discovered and removed in the modeling activity and the actors were acquainted with the "process way of thinking". It was difficult to evaluate the duration for some activities, to empirically determine the percentages for the output distribution in decision points etc. During verification several inconsistencies in the models have been discovered, e.g. when the activity durations are multiplied by the process frequency the result is much higher than the number of working hours of the available resources.

\section{Analysis of key business processes on the basis of their models}

In this activity a qualitative and a quantitative analysis of the current (AS-IS) processes is conducted. It very often appears that the same processes are implemented in a different way for different areas (in different organizational units). According to our experience organizational units are usually not aware of these differences, so the BPC project is a good opportunity to acquaint them with this problem and unify the processes of the same type. The unification can lead to the improvement of customer orientation.

For example, the Administrative Processes group at the Ministry includes some of the most frequently executed processes and are therefore very interesting for a detailed examination and analysis in the BPC and IS project, as significant improvements in efficiency can be expected. At the initiation stage of the project more than 30 processes were identified in this group, however, some of them were of the same type, but for different areas (e.g. elementary schools, high schools, universities) and therefore their substantial activities were executed in different departments.

The analysis results can be presented at different levels. In case of a group of similar processes there are findings for the group as a whole, and then for each process. Apart from the findings of the analysis some data from the models and process documentation, which might be of interest in the redesign phase, are presented in the analysis report.

At this point at the Ministry several processes were analyzed using simulation as well. Processes for such detailed analysis were selected by using the criteria such as: frequency of process execution, quantity of consumed resource, level of observed problems, etc.

\section{Redesign}

Process redesign based on the findings of the analysis calls for the application of creative thinking techniques (such as brainstorming). Firstly, groups of similar processes that can be defined as one TO-BE process are identified and then new, renovated processes designed.

As mapping between AS-IS and TO-BE processes is not 1:1, proposed new processes are relabeled. We use letters to label TO-BE processes. Usually one TO-BE process corresponds to sev- 
eral unified AS-IS processes. Two tables which present mapping between the current and the renewed processes (and vice versa) are built (see Tables 2 and 3 ).

Table 2. Mapping of the existing to the renovated processes (A segment of the entire catalogue)

\begin{tabular}{|c|c|c|c|}
\hline $\begin{array}{l}\text { Organizational } \\
\text { unit }\end{array}$ & $\begin{array}{c}\text { Existing } \\
\text { process } \\
\text { label }\end{array}$ & Existing process name & $\begin{array}{c}\text { Renovated } \\
\text { process label }\end{array}$ \\
\hline 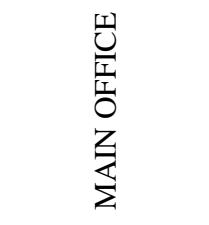 & 5.1 & Application acceptance & $5 . X$ \\
\hline \multirow{3}{*}{ 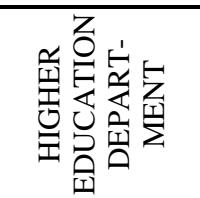 } & 5.6 & Administrative processes in the higher education sector & 5 \\
\hline & 5.6 .1 & Appeal against a decision of a hall of residence & $5 . \mathrm{E}$ \\
\hline & 5.6 .2 & $\begin{array}{l}\text { Entry in the records of higher education institutions and pri- } \\
\text { vate university teachers }\end{array}$ & 5.A \\
\hline \multirow{7}{*}{ 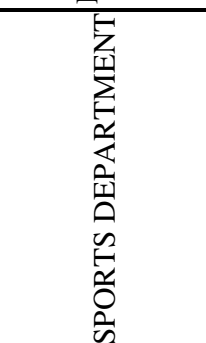 } & 5.8 & Administrative processes in the sports department & 5 \\
\hline & 5.8 .1 & Entry in the records of private sports affaire officer & $5 . \mathrm{A}$ \\
\hline & 5.8 .2 & Entry in the records of professional sportsmen/women & $5 . \mathrm{A}$ \\
\hline & 5.8 .3 & Entry in the records of sports facilities & $5 . \mathrm{A}$ \\
\hline & 5.8 .4 & $\begin{array}{l}\text { Entry in the records of societies of public interest in the field } \\
\text { of sport }\end{array}$ & 5.A \\
\hline & 5.8 .5 & $\begin{array}{l}\text { Promotion of the employees in the field of sport to a higher } \\
\text { professional title }\end{array}$ & 5.A \\
\hline & 5.8 .6 & Qualification examinations & 5.D \\
\hline
\end{tabular}

As evident from the two tables, the existing-to-the-renovated-processes mapping is not just about re-labeling, regrouping and unification. The main achievement of different classification (and consequently different labeling) is completely changed view on business processes. Before the change the processes had been grouped by departments (e.g. higher education department processes, sports department processes etc.). After the changes employees started to understand that process view is horizontal (process flows through several departments), that processes are crossdepartmental. This was one of the main breakthroughs in the employees understanding of business processes.

Table 3. Mapping of the renovated to existing the processes (A segment of the entire catalogue)

\begin{tabular}{|c|c|c|}
\hline $\begin{array}{c}\text { Renovated } \\
\text { process }\end{array}$ & Renovated administrative process name & Existing process labels \\
\hline 5.A & $\begin{array}{l}\text { Maintenance of records of societies, private officers, } \\
\text { professional and top-level sportsmen/women, legal } \\
\text { personalities, and sports facilities. Satisfying the condi- } \\
\text { tions for financing of a private kindergarten. }\end{array}$ & $\begin{array}{c}5.2 .1,5.5 .1,5.6 .2,5.7 .1,5.8 .1,5.8 .2 \\
5.8 .3,5.8 .4,5.8 .5,5.9 .2,5.9 .5,5.10 .4 \\
5.10 .6\end{array}$ \\
\hline 5.B & $\begin{array}{l}\text { Consent to the establishment of education, science, or } \\
\text { sport institution act }\end{array}$ & 5.9 .3 \\
\hline $5 . \mathrm{C}$ & Nostrification of foreign diplomas & 5.10 .1 \\
\hline 5.D & $\begin{array}{l}\text { Qualification examinations in the fields of education } \\
\text { and sport }\end{array}$ & $5.8 .6,5.10 .5$ \\
\hline 5.E & Second level processes & $\begin{array}{c}5.2 .2,5.3 .1,5.3 .2,5.4 .1,5.6 .1,5.9 .1 \\
5.9 .4,5.9 .6,5.10 .2 \\
\end{array}$ \\
\hline $5 . \mathrm{X}$ & Application acceptance & 5.1 \\
\hline
\end{tabular}


Proposals of new processes are described by using standardized forms. Like for the findings of the current processes analysis, proposals for changes are presented in two levels: for each process group and then for each individual process. At the process level proposals are mostly related to unification and IS. Proposals were made on the basis of the analysis of the process maps, descriptions, simulation, regulations etc. The standardized form for proposals consists of the following elements:

- (Sub)Process name. Example: Maintenance of records of societies, private officers, professional and top-level sportsmen/women, legal personalities, and sports facilities. Satisfying the conditions for financing of a private kindergarten

- (Sub)Process label. Example: 5.A

- Corresponding processes labels. Example: 5.8.4, 5.9.5, 5.6.2, 5.7.1, 5.8.1, 5.10.6, 5.8.5, 5.8.2, 5.6.2, 5.10.4, 5.5.1, 5.9.2, 5.8.3, 5.2.1

- Process owner. An organizational unit, which is the process owner. As the same process can be performed in different organizational units for different types of applications (e.g. Educational department and Sports department) it may have several process owners. However one process manager (e.g. Ministry Secretariat) is appointed, who has the responsibility to coordinate process changes, IS support activities etc.

- Process model. Renovated process model. The enhanced process maps (EPM) technique is used.

- Event(s). One or several events, by which the process execution is fired. Example: Submission of an application.

- Input. Input in the renovated process. Example: An application with the attached required documentation.

- Description. Verbal description of the renovated process.

- Output. The output (result) of the renovated process. Example: An archived decision statement and a record entry.

- Changes by activities. Detailed descriptions of changes for each activity of the existing processes compared to the renovated process.

- Other findings and proposals. Discovered weaknesses of the existing processes and suggestions related to the process as a whole, process group, or interactions between the processes.

- Resources. Required human resources for each activity of the renovated process. Proposed changes of regulations are anticipated.

- Findings, relevant to IS support. Descriptions of the necessary IS support activities and proposed future development of IS support. Unification of similar processes is one of the main driving forces for changes in this field. Example: Unification of records databases and applications, document systems improvement, digital signature introduction etc.

Due to limitations and constraints all proposals have to be discussed with the management. Therefore several COULD models (Harmon, 2003) are usually proposed. However, when all the viewpoints are reconciled and final proposals verified, then SHOULD models, which are to be implemented, are built and process owners appointed. This includes reorganization proposal and IS projects proposals. 
In the case of the Ministry the main guidance in the redesign stage was the goal to simplify the processes and provide better services for customers (institutions, citizens etc.). Secondary goals are shorter cycle times, unburdening of employees, and lower costs.

There were several cases of the same process carried out differently in different areas. For instance the process "Promotion of the Employees to a Higher Professional Title" had been executed in a different way in the sports department (labeled as 5.10.6) and in the educational department (5.8.5). The renovated process labeled 5.C is only one for both departments. Of course the substantial activity Professional Consideration (5.C.13) is specific in both departments and requires different professionals with specific knowledge. The new process also has one process owner who has among other business process management responsibilities also the responsibility to harmonize all the necessary future changes in the process in both departments. The fact that from the point of view of process flows several processes were unified makes the whole administrative function of the Ministry less complex in the eyes of the customers and also IS projects are simplified.

Together with process change several organizational changes were proposed. At this point we faced rather strong limitations, as the upper part of the organizational structure is defined by governmental regulations. Although the proper process organization is currently still not possible, some major movements were made in this direction. The financial department for instance is the owner of all the financial processes and has now cross-departmental jurisdiction. Determining process owners, individuals responsible for process design and performance that are accountable for sustaining the gain and identifying future improvement opportunities on the process is very important for the successfulness of BPC project.

\section{Reconstruct and Evaluate}

The Ministry has started the reconstruction phase. It is quite limited in IS projects planning and implementation, because it depends on the internal regulation for all governmental institutions in Slovenia. However, the project has certainly brought about many benefits for them. One of the main benefits is that the processes are now known and are performed in a much more uniform way than before. To make the new way of work easier and to acquaint people with new renewed business processes the models are published on the internal Ministry's web pages. Is simplifies change management and also provides an unambiguous way of process implementation.

\section{Discussion and Conclusion}

We have used the previously described (see Business Process Change section) BPO model to roughly estimate the improvement of the business process maturity level at the Ministry as the consequence of the BPC project. As it is proven that the BPO level is positively related to the business performance (McCormack \& Johnson, 2001) we used this analysis as the measure of the project success.

Before this project the Ministry was clearly at the first level of the business process maturity model. Processes were neither documented nor defined. Jobs were organized strictly upon the traditional functions. Departments that should be the owners of the processes (e.g. financial department) had no influence on these processes (e.g. financial processes) performance in other departments. Now the Ministry is moving from the first level to the second level with some elements of the third level. The processes are documented, known and performed in a much more uniform way than before, models are published on the organizational internal web pages, process managers are appointed. As quality services require continuous improvement of inputs and processes (Hendrick, 1994), a process management environment has to be developed. The process managers have responsibility to harmonize all the necessary future changes in all departments, so 
changes to the processes must now go through a formal procedure. The financial department for instance is the owner of all the financial processes and now has cross-departmental jurisdiction. Therefore we can say that jobs include a process aspect.

A question that could arise is whether more radical changes could have been done. Considering the characteristics of the public sector described in the section on BII Methodology, we believe that such radical changes are not possible. Moreover, the authors of the BPO maturity model suggest that it is not possible to skip levels. Each organization should grow and go through all these levels.

Even though it is not a real breakthrough, this change at the Ministry is an important step. The crucial achievement is that the way of thinking has been changed. Employees now understand the concept of the business process and this is a good foundation to proceed with the process of growing in the sense of BPO.

Based on our experience it is very important and sometimes difficult to correctly identify key business processes and their sub-processes that are modeled. We suggest that special attention should be paid to this activity of the BPC project. Some difficulties at later stages of the project at the Ministry were caused by the fact that some of the processes were not identified during the diagnose phase. We believe that the reason might be poor understanding of the business process concept by the project team members from the Ministry. Although we were aware of the importance of full understanding of this concept, we suggest that even more attention should be paid to this activity.

Although the public sector has many limitations (e.g. rigid structures and political reasons) we believe that BPC is of importance also for this sector especially to successfully execute egovernment. The paper presented the methodology for BPC projects in the public sector. The methodology is based on the general framework for BPC methodologies, techniques and tools (Kettinger et al., 1997) and is customized for governmental institutions due to their specifics, e.g. projects radicalness. It has been successfully employed in some process improvement projects, e.g. in a BPC project at one of the Slovene ministries and this project has been used in the paper as a case study, and is applicable to other governmental organizations.

We hope that more attention will be given to business process improvement in the public sector, especially among practitioners. E-government initiatives or EPR projects are the areas where $\mathrm{BPC}$ is extremely important.

Lately, business process management methods and systems that enable process modeling, analysis, simulation and also their automation and performance measurement are emerging (Smith \& Fingar, 2003). Such systems will be applicable to governmental processes as well and will probably change process improvement methodologies. The adoption of the proposed methodology with regard to business process management is left for our future work.

\section{References}

Al-Mashari, M., \& Zairi, M. (1999). BPR implementation process: An analysis of key success and failure factors. Business Process Management Journal, 1, 87-112.

Bosilj-Vuksic, V., Indihar Stemberger, M., Jaklic, J., \& Kovacic, A. (2002). Assessment of e-business transformation using simulation modelling. Simulation, 12, 731-744.

Cats-Baril, W., \& Thompson, R. (1995). Managing information technology projects in the public sector. Public Administration Review, 55, 559-566.

Davenport, T. H. (1998). Putting the enterprise into the enterprise system. Harvard Business Review, 4, 121-131. 
Desel, J., \& Ervin, T. (2000). Modeling, simulation and analysis of business processes. In W. van der Aalst, et al. (Eds.), Business process management (pp. 129-141). Berlin: Springer Verlag.

Gil-Garcia, J. R., \& Pardo, T. A. (2005). E-government success factors: Mapping practical tools to theoretical foundations. Government Information Quarterly, 22, 187-216.

Hammer, M. (2004). Deep change: How operational innovation can transform your company. Harvard Business Review, 4, 84-93.

Hammer M., \& Champy, J. (1993). Reengineering the corporation. New York: Harper Collins Books.

Harmon, P. (2003). Business process change: A manager's guide to improving, redesigning, and automating processes. San Francisco: Morgan Kaufmann Publishers.

Hendrick, R. (1994). An information infrastructure for innovative management of government. Public Administration Review, 54, 543-550.

Kettinger, W.J., Teng, T.C., \& Guha, S. (1997). Business process change: A study of methodologies, techniques, and tools. MIS Quarterly, 1, 55-81.

Kumar, V., Maheshwari, B., \& Kumar, U. (2002). ERP systems implementation: Best practices in Canadian government organizations. Government Information Quarterly, 19, 147-172.

Lockamy, A., \& McCormack, K. (2004). The development of a supply chain management process maturity model using the concepts of business process orientation. Supply Chain Management: An International Journal, 9, 272-278.

McCormack, K., \& Johnson, W. (2001). Business process orientation: Gaining the e-business competitive advantage. Delray Beach, FL: St Lucie Press.

Popovic A., \& Jaklic J. (2004). Problems of business process simulation modelling [In Slovene]. In S. Novakovic et al. (Eds.), Proceedings of the Slovene Informatics Conference. Ljubljana, Slovenian Society Informatika, 56-61.

Smith, H., \& Fingar, P. (2003). Business process management: The third wave. Tampa, FL: Meghan-Kiffer Press.

Tenner, A. R., \& DeToro, I. J. (1997). Process redesign: The implementation guide for managers. Reading, MA: Addison-Wesley.

Thompson, J. R. (2000). Reinvention as reform: Assessing the national performance review. Public Administration Review, 6, 508-521.

Trkman, P. Indihar Stemberger, M., \& Jaklic, J. (2005). Information transfer in supply chain management. Informing Science and IT Education Conference 2005 (InSITE 2005), 2, 559-573. Available at http://2005papers.iisit.org/I46f91Trkm.pdf

\section{Biography}

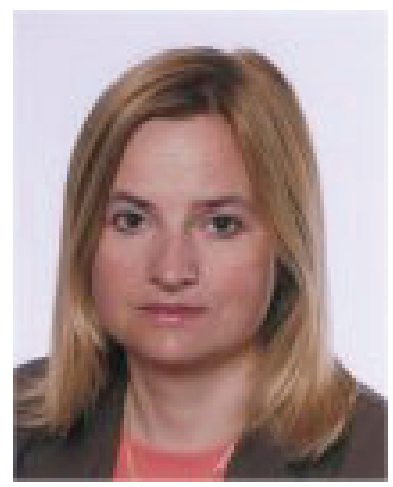

Mojca Indihar Stemberger is an associate professor of information management at the Faculty of Economics, University of Ljubljana, Slovenia. Her research interests include business process renovation, ebusiness and decision support systems. She received her Master in Computer and Information Science degree in 1996, and her Ph.D. in Information Science in 2000 from the University of Ljubljana. Dr. Indihar Stemberger has published several scientific and professional papers in Slovenia and abroad. She has been a consultant for business process change on several projects in public and private sector. From 2001 she has been a president of Slovene information management conference and she is a conference chair of InSITE 2007 conference. 


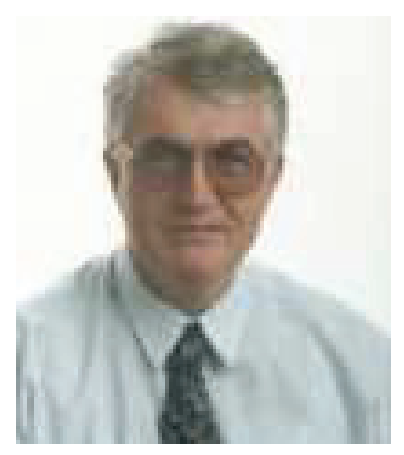

Andrej Kovacic is an associate professor at the Faculty of Economics, University of Ljubljana, Slovenia. He was engaged as consultant and project manager on several Business Process Reengineering (BPR) and Information System (IS) development projects. He is a certified: Expert on Management Consulting and Information Technology, and IS Auditor. He is also Editor of the Slovene review for business informatics Uporabna informatika, and member of Slovene Society of Informatics.

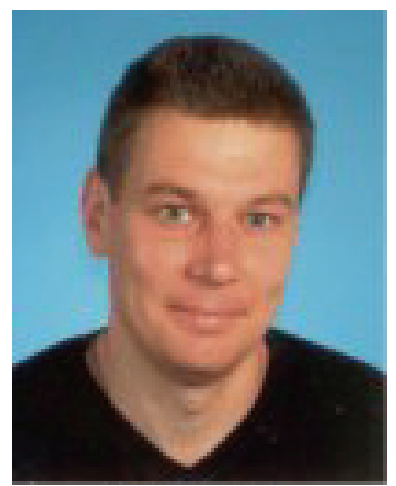

Jurij Jaklic is an associate professor at the Faculty of Economics, University of Ljubljana, Slovenia. His main research interests are business process renovation, business process simulation modelling, decision support systems, and data management. He received his Master Degree in Computer Science in 1992 from the University of Houston and his PhD in 1997 from the University of Ljubljana, Slovenia. He has published several papers and book chapters. Since 2003, he is a member of editorial board of Slovene professional journal on information systems. He has been a consultant for business process change on several projects in public and private sector. 